\title{
Cell Proliferation and Antioxidative Effects of Ultrasonic Coffee Extracts
}

\author{
Hyunwoo Jin ${ }^{1,2, \dagger}$ \\ ${ }^{I}$ Department of Clinical Laboratory Science, College of Health Sciences, \\ Catholic University of Pusan, Busan 46252, Korea \\ ${ }^{2}$ Construction of Diagnosis System to Create an Ecosystem for Elder-friendly Medical Health Care, \\ Brain Busan 21 Program, Graduate School, Catholic University of Pusan, Busan 46252, Korea
}

Recently, coffee is the most popular beverage for modern people. A great number of substances are found in coffee beans and have been studied for many years such as aliphatic and aromatic compounds. However, studies on the physiological activity of coffee extracts are insufficient. This study was performed to determine the contents of caffeine and chlorogenic acid in coffee extracts according to the solvent and to investigate the physiological activity of coffee extracts. Coffee extracts were extracted by ultrasonication method with various types of solvents including distilled water, ethanol, and other organic solvents under $50^{\circ} \mathrm{C}$ and $80^{\circ} \mathrm{C}$. The contents of caffeine and chlorogenic acid in coffee extracts were determined by Liquid Chromatography-Mass Spectrometry (LC-MS). Also, cytotoxic and antioxidative effects of coffee extracts were evaluated with MTT and DPPH assays to analyze the physiological activity. As a result, it was confirmed that caffeine and chlorogenic acid contents were extracted in distilled water with the highest rate. Antioxidative activity was observed below 10-fold dilute of coffee extracts, however cytotoxicity was not observed. In conclusion, distilled water was the best solvent for extracting caffeine and chlorogenic acids from coffee bean with ultrasonication and these coffee extracts are less cytotoxic in human skin cell lines and have antioxidant effect.

Key Words: Coffee extract, Caffeine, Chlorogenic acid, Antioxidant activity, LC-MS

\begin{abstract}
최근 현대인들의 생활수준의 향상으로 건강과 삶을 중 요시하고 행복을 추구하는 생활방식으로 인식의 변화가 있고 자연스럽게 건강과 삶의 질을 높이는 소비 형태로 관심이 변화하여 상품의 효능과 효과를 중요하게 생각한 다. 그 중 천연물질들의 성분이 다양한 효능을 가지는 것 을 알게 되면서 단순히 인간의 삶을 유지하려는 현대인들 에게 질병을 예방하고 노화 예방과 건강유지에 도움을 줄 수 있는 천연자원으로 인식하고 있다(Hur, 2015). 천연물 을 추출하는 방법으로 전통적 방법인 열수출법, 고온용매 추출법, 기계 압착법 등을 주로 사용하지만 이러한 전통 적 방법을 통한 추출은 추출용매의 소모량이 많고 열에
\end{abstract}

의해 변성이 될 수 있다는 단점을 가지고 있다. 이에 최근 천연물질에서 유용 성분을 추출하는데 초음파처리법, 효 소추출법, 초임계 유체법 등의 새로운 기술들이 개발되었 고 이 중 초음파 추출법은 간편하고 효율적인 추출기법으 로 천연물질 추출에 다양하게 활용한다(Hwang and Park, 2015).

커피 생두(Green Coffee Beans)는 커피나무의 열매(Coffee cherry) 중에 있는 씨앗에서 외피를 박피하여 세척하고 건 조한 것을 말한다. 커피의 주요 원료인 커피 생두의 구성 성분으로는 수분, 탄수화물, 지방질, 단백질, 무기질, $\mathrm{Caf}-$ feine과 Chlorogenic acid으로 이루어져 있고 이의 함량은

* Received: October 13, 2017 / Revised: November 7, 2017 / Accepted: November 9, 2017

${ }^{\dagger}$ Corresponding author: Hyunwoo Jin. Department of Clinical Laboratory Science, College of Health Sciences, Catholic University of Pusan, Busan 46252, Korea.

Tel: +82-51-510-0567, Fax:+82-51-510-0568, e-mail: jjinhw@cup.ac.kr

(C) The Korean Society for Biomedical Laboratory Sciences. All rights reserved.

(c) This is an Open Access article distributed under the terms of the Creative Commons Attribution Non-Commercial License (http://creativecommons.org/licenses/by-nc/3.0/) which permits unrestricted non-commercial use, distribution, and reproduction in any medium, provided the original work is properly cited. 
생산환경이나 품종에 따라 조금씩 차이가 있다. 이러한 커 피는 전 세계적으로 가장 널리 음용하는 음료 중 하나로 한국에서도 커피의 수입량은 매년 증가하고 있고 최근 커 피의 활용 증가와 더불어 다양한 방법을 통해 커피의 생 리활성 효과를 증명하기 위한 연구가 진행되고 있다(Lee et al., 2016; Kim et al., 2018).

커피 중 가장 잘 알려진 성분인 caffeine은 커피 외에도 다양한 품목에 함유되어 있는 xanthine계 화합물로 커피 콩에서 처음 발견된 흥분제의 한 종류이며 부신피질 호르 몬 분비를 촉진하여 순환기 계통의 운동을 늘리며 중추신 경을 활성화 시키는 등 다양한 효과를 보이는 것으로 알 려져 있다(Cho, 2015). 커피의 항산화 효과에 대한 연구로 페놀화합물이나 chlorogenic acid의 함량이 커피에서 높은 것으로 나타났고 바이러스 감염에 의한 영향을 막는 효과 를 가지고 있다는 보고가 있다. 또한 커피는 커피를 녹이 는 용매에 따라 여러 종류의 균에 대한 항균작용의 효과 를 보이고 노화와 천식에도 효과를 보인다는 보고가 있다. 장기간 커피의 섭취는 2형 당뇨 발병을 낮추고 정신과 신 경질병인 파킨슨병과 알츠하이머 질병의 발병에도 효과 를 보인다는 연구가 보고되고 있다(Campos-Florián et al., 2013).

Chlorogenic acid는 green coffee bean을 포함한 다양한 식물이나 식물의 일부에서 생성되는 천연 생성물이다. 화학적으로 caffeic acid와 quinic acid, 3-O-caffeoylquinic acid (3-CQA)의 에스테르이고 다른 이성질체로는 cryptochlorogenic acid (4-CQA)와 neo-chlorogenic acid (5-CQA)가 있다. Chlorogenic acid는 민감한 위장을 가진 사람들에게 문제가 되는 것으로 알려진 커피 성분 중 하나이다. 반면 폴리페놀 화합물로서 chlorogenic acid는 강한 antioxidant로 세포 및 모든 기관의 산화적 퇴행으로부터 보호하는 역할 을 하여 건강에 도움을 주는 것으로 알려져 있다(Farah et al., 2008; Jeszka-Skowron et al., 2016b).

이와 같이 커피는 최근 생활수준의 향상에 따라 애용하 는 쓴맛, 신맛 등의 고유의 독특한 맛과 향이 어우러진 대 표적 기호식품으로 이의 효능들이 알려지고 있다. 하지만 커피의 효능이 밝혀짐에 따라 다양하게 식품으로 이용되 고 있지만 커피 생두 추출물의 용매와 추출법에 따른 성 분 함량 변화와 생리활성에 관한 연구는 미흡한 실정이다. 따라서 본 연구에서는 커피 생두를 대상으로 용매에 따른 커피 추출물 내 caffeine 및 chlorogenic acid의 함량을 분석 하고 커피 추출물의 생리활성 효과를 확인하고자 하였다.

커피 추출물은 생두(Arabica)를 이용하여 수세한 후 동
결건조하여 시료로 사용하였다. 용매에 따른 chlorogenic acid의 함량 분석을 위하여 각 용매(ethanol, 식물성 ethanol, distilled water) $100 \mathrm{~mL}$ 에 각각 생두 $30 \mathrm{~g}$ 을 넣고 sonicator (VCX 500, Sonics \& Material Inc.)를 이용 (amplitude; 70\% of $400 \mathrm{~W}, 3.0 \mathrm{sec}$ pules, $1.0 \mathrm{sec}$. rest)의 조건으로 sonication 하였으며 추출 종료 후 caffeine과 chlorogenic acid의 함량 분석을 위하여 $0.2 \mu \mathrm{m}$ syringe filter로 여과하여 사용하였다. 또한 온도 변화에 따른 chlorogenic acid의 함량을 분석하 기 위하여 $50^{\circ} \mathrm{C}$ 와 $80^{\circ} \mathrm{C}$ 에서 2회 반복하여 진행하였으며 제조된 시료는 $-20^{\circ} \mathrm{C}$ 에 보관하여 사용하였다.

커피 생두 내 주요 성분인 Caffeine과 Chlorogenic acid 의 함량을 분석하기 위하여 LC-MS (6530 Accurate-Mass Q-TOF LC/MS, Agilent Technologies)를 사용하여 측정하였 다. 분석에 사용 된 칼럼은 Kinetex 2.6u C18 100A (100 X $3.00 \mathrm{~mm}$, Phenomenex, Torrance, CA, USA) 칼럼을 사용하 였고, 칼럼온도는 $40^{\circ} \mathrm{C}$ 로 분석하였다. 유속은 $0.3 \mathrm{~mL} / \mathrm{min}$ 으로 흘려 주었으며 주입량은 $3 \mu \mathrm{l}$ 였다. 이동상은 $0.1 \%$ formic acid 수용액과, acetonitrile에 녹인 $0.1 \%$ formic acid 를 사용하였으며 검출파장은 $325 \mathrm{~nm}$ 에서 검출하였다.

커피 추출물이 세포에 독성을 나타내는 농도를 확인하 기 위하여 동물 유래 섬유아세포 cell line인 vero cell과 인 체 유래 섬유아세포 cell line인 CCD-986sk, 피부각질세 포 cell line인 $\mathrm{HeCaT}$ cell을 3-(4,5-dimethylthiazol-2-yl)-2,5diphenyltetrazolium bromide (MTT) assay로 변형하여 실험 하였다. 실험에 사용된 Cell의 농도를 $1 \times 10^{5}$ 개/mL로 조 정하여 96 well plate에 $100 \mu \mathrm{l}$ 씩 분주 후 $37^{\circ} \mathrm{C}, 5 \% \mathrm{CO}_{2}$ 조 건에서 24시간 배양하였다. $0.2 \mu \mathrm{m}$ syringe filter로 여과한 커피 생두 추출물을 농도 별로 $100 \mu \mathrm{l}$ 씩 분주 후 $150 \mathrm{rpm}$ 에서 5 분 shake하고 $37^{\circ} \mathrm{C}, 5 \% \mathrm{CO}_{2}$ 조건에서 48 시간 및 72 시간 배양하였다. $5 \mathrm{mg} / \mathrm{mL}$ in PBS 농도인 MTT 용액 (Ambresco)을 준비하여 각 well에 $20 \mu \mathrm{l}$ 씩 분주하여 150 $\mathrm{rpm}, 5$ 분 shake하고 $37^{\circ} \mathrm{C}, 5 \% \mathrm{CO}_{2}$ 에서 2 시간 배양하였다. 배지를 최대한 제거하고 dimethyl sulfoxide (DMSO)를 200 $\mu$ 씩 분주한 뒤 $150 \mathrm{rpm}$ 에서 5 분간 교반하여 ELISA reader 기를 이용하여 $595 \mathrm{~nm}$ 에서 흡광도를 측정하였다.

커피 추출물을 농도 별로 $1,10,10^{2}, 10^{3}, 10^{4}$ 배 희석하여 준비하였으며, 에탄올에 용해시킨 $0.2 \mathrm{Mm}$ 의 2,2-diphenyl1-picrylhydrazyl (DPPH) 용액 $190 \mu \mathrm{l}$ 를 96 well plate에 각각 분주한 후 커피 추출물 희석액을 $10 \mu \mathrm{l}$ 분주하여 $37^{\circ} \mathrm{C}$ 에서 30 분간 반응시켰다. 시료액의 대조군으로 멸균 증류수를 사용하였으며 반응 후 $550 \mathrm{~nm}$ 에서 흡광도를 측정한 다음 시료 첨가군과 무첨가군 사이의 흡광도의 차이를 백분율 
$(\%)$ 로 표시하였다.

커피 원두에 포함된 chlorogenic acid 및 caffeine의 용매 의 종류에 따른 추출 효율을 분석하기 위해 식물성 에탄 올, 합성 에탄올, 증류수의 세 가지 용매를 이용하였다. 또 한 용매의 종류에 따른 chlorogenic acid 추출 효율을 비교 하기 위해 HPLC LC-MS 분석을 실시하였고, chlorogenic acid의 정확한 물질 분석을 위해 SIGMA 사로부터 표준물 질인 합성 chlorogenic acid (Sigma-Aldrich Co., St.Louis, MO, USA)을 구입하여, 추출물 내에 포함된 chlorogenic acid과 의 일치성을 확인하였으며, 추가적으로 표준물질을 이용
한 standard curve를 그려서 추출물 내의 정확한 chlorogenic acid 농도를 확인하였다(Fig. 1A).

표준물질을 이용한 표준곡선을 통해 용매의 종류에 따른 chlorogenic acid 함량을 분석한 결과 증류수를 용매로 했을 때 chlorogenic acid 추출 농도는 $59.54 \mathrm{mg} / \mathrm{L}$, 식물성 에탄올 을 용매로 했을 때 chlorogenic acid 추출 농도는 $19.2 \mathrm{mg} / \mathrm{L}$, 합성 에탄올을 용매로 했을 때 chlorogenic acid 추출 농도 는 $55.2 \mathrm{mg} / \mathrm{L}$ 로 증류수를 용매로 이용했을 때 chlorogenic $\mathrm{acid}$ 의 추출 효율이 가장 높은 것을 확인하였다. Chlorogenic acid 함량의 정확한 분석을 통해 표준물질 이용해 우

A

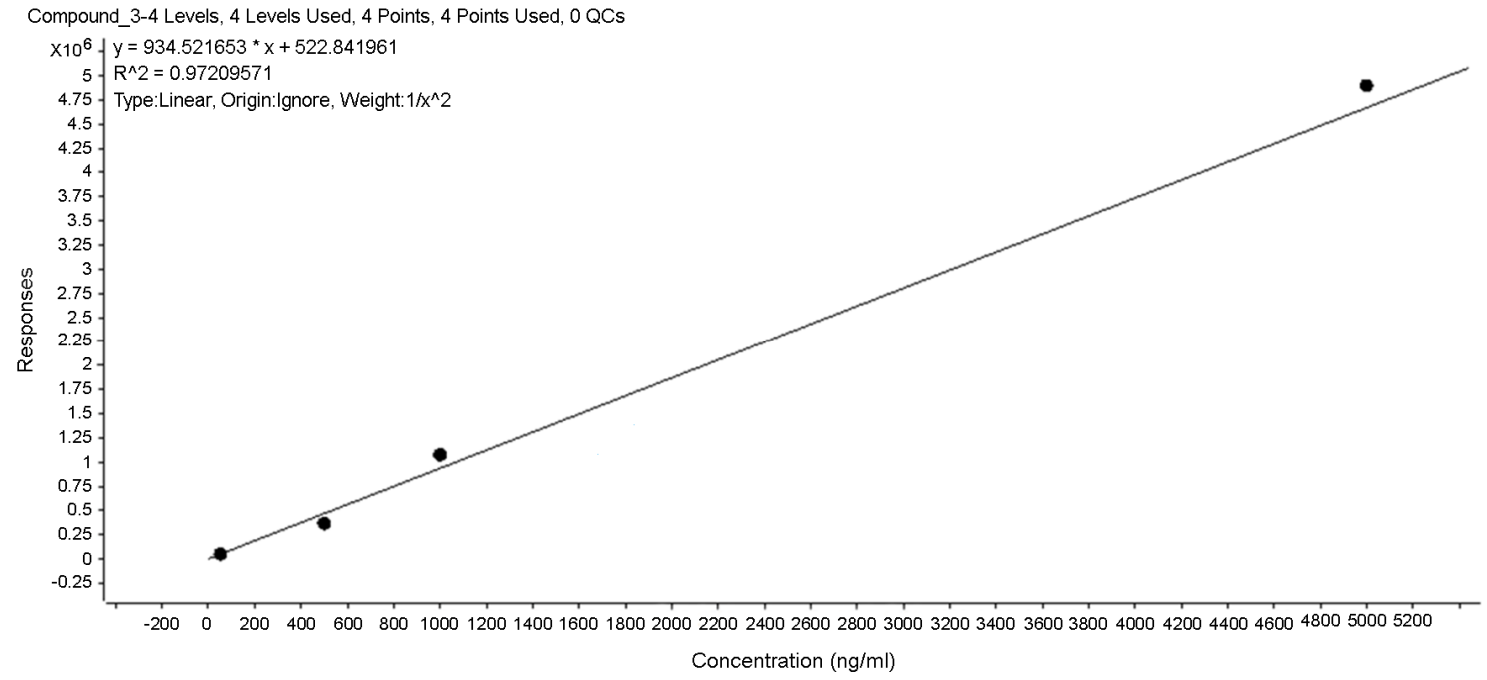

B

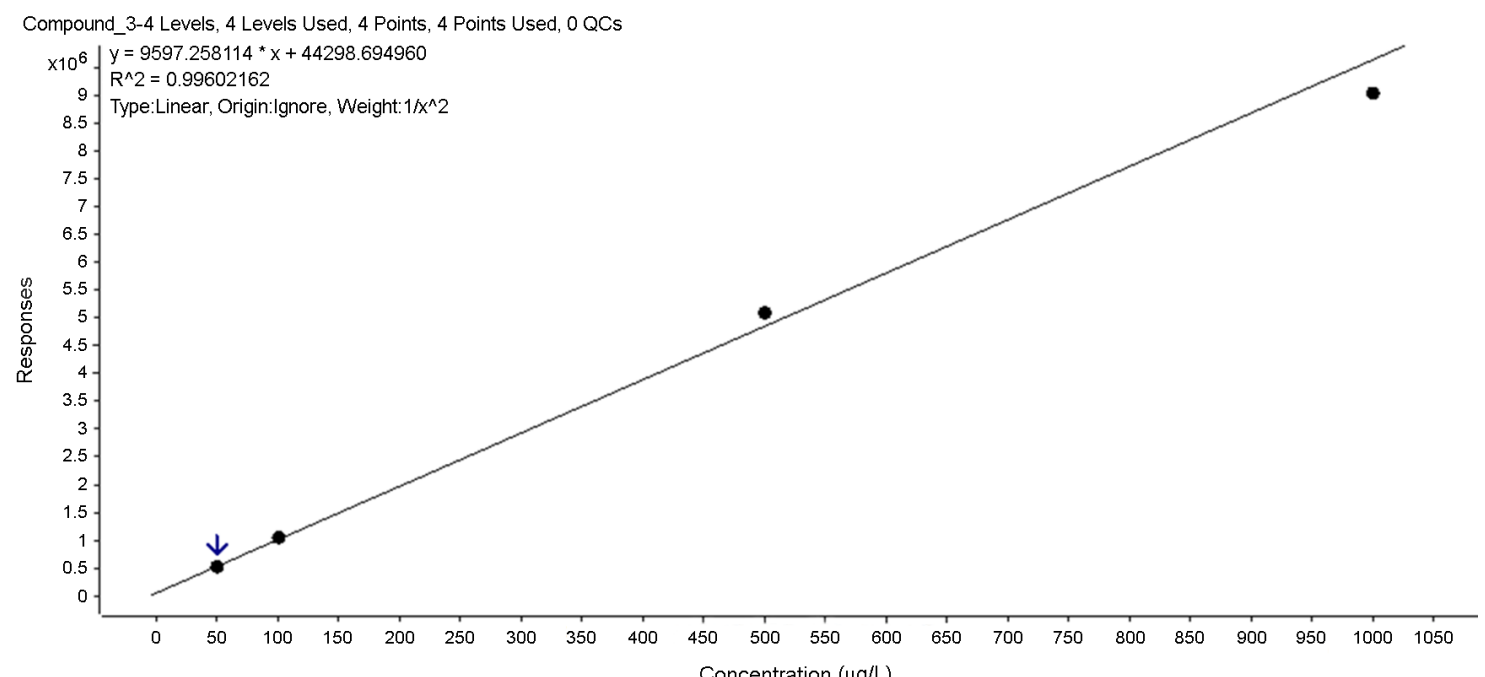

Fig. 1. Standard curve of chlorogenic acid (A), caffeine contents (B). 
선적으로 LC-MS 조건을 수립(Peak 위치: 약 5.28)한 후 세 종류의 용매를 이용한 추출물에 포함된 chlorogenic acid 위치를 확인하였다(Fig. 2A).
커피 원두에서 chlorogenic acid 추출 시 caffeine이 커피 생두 extract에서 함께 추출되며, chlorogenic acid와 caffeine 의 분자량 또한 유사하기 때문에 정확한 물질 분석을 위

A

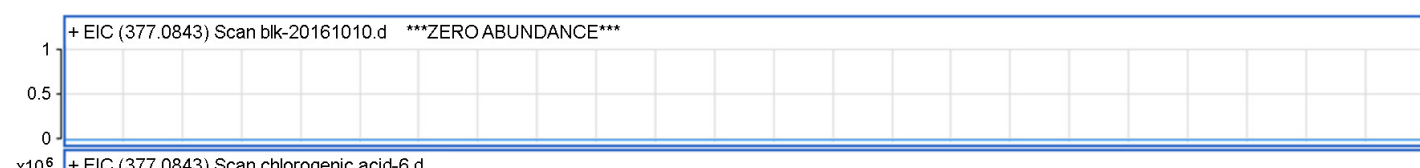
$\times 10^{6}+$ EIC (377.0843) Scan chlorogenic acid-6.d
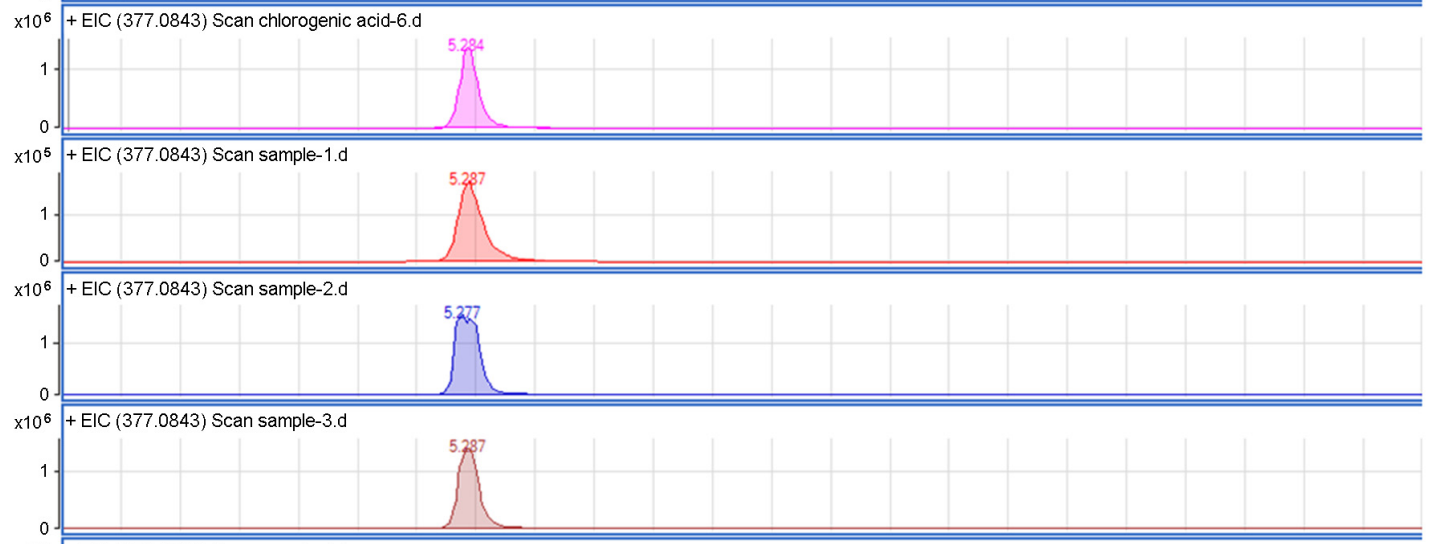

$\times 10^{5}+$ EIC (377.0843) Scan sample-4.d

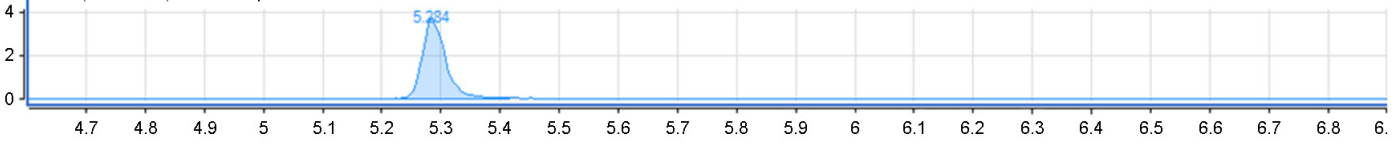

B

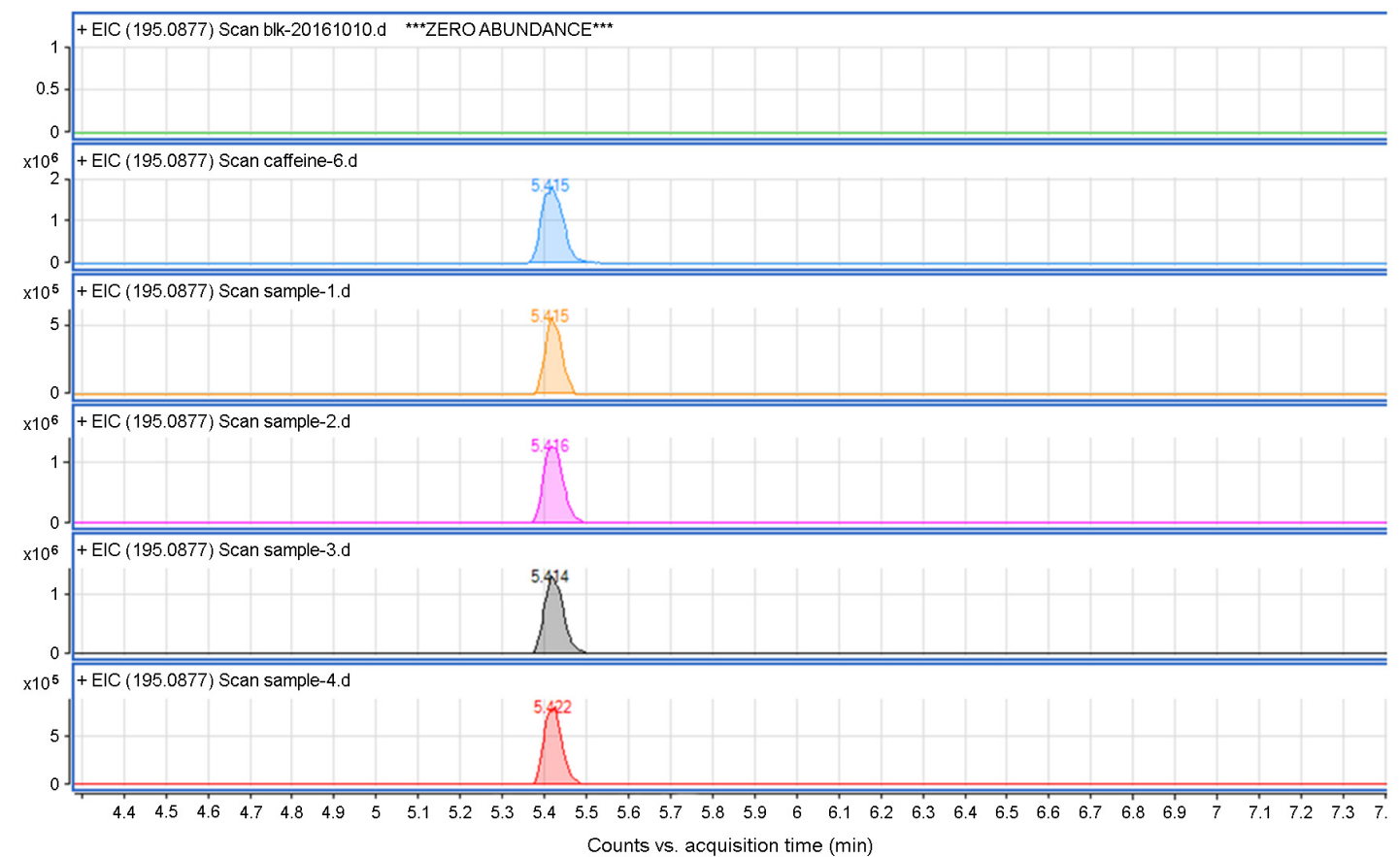

Fig. 2. Comparison of chlorogenic acid (A) and caffeine (B) peak with standard. 
해 커피 생두 extract에 포함된 caffeine의 양 및 추출 효율 도 함께 분석하였다. 용매의 종류에 따른 caffeine 추출 효 율을 비교하기 위해 LC-MS 분석을 실시하였고, caffeine의 정확한 물질 분석을 위해 SIGMA 사로부터 합성 caffeine 표준물질을 구입하여, 추출물 내에 포함된 caffeine의 일 치성을 확인하였으며, 표준곡선으로 추출물 내의 정확한 caffeine 농도를 확인하였다(Fig. 1B).

표준물질을 이용한 표준곡선을 통해 용매의 종류에 따 른 caffeine 함량을 분석한 결과 증류수를 용매로 했을 때 caffeine 추출 농도는 $127.62 \mathrm{mg} / \mathrm{L}$, 식물성 에탄올을 용매로 했을 때 caffeine 추출 농도는 $15.14 \mathrm{mg} / \mathrm{L}$, 합성 에탄올을 용매로 했을 때 caffeine 추출 농도는 $25.28 \mathrm{mg} / \mathrm{L}$ 로 증류수 를 용매로 이용했을 때 또한 caffeine의 추출 효율이 가장 높은 것을 확인하였다. Caffeine 함량의 정확한 분석을 통 해 표준물질 이용해 우선적으로 HPLC LC-MS 조건을 수 립(Peak 위치: 약 5.41)한 후 세 종류의 용매를 이용한 추 출물에 포함된 caffeine의 위치를 chlorogenic acid과 정확히 구분하여 확인하였다(Fig. 2B). 커피 원두로부터 caffeine과 chlorogenic acid의 최대 추출 효율을 위한 최적 온도 선정 을 위해 기존 연구들을 기준으로 하여, 이전 시험 결과에 서 chlorogenic acid 추출 효율이 가장 높았던 증류수를 용 매로 하여 $50^{\circ} \mathrm{C}$ 와 $80^{\circ} \mathrm{C}$ 두 온도 조건에서 chlorogenic acid 추출 효율을 비교하였다.

그 결과, 증류수를 용매로 하였을 때, $50^{\circ} \mathrm{C}$ 조건에서 caffeine $0.014 \mathrm{mg} / \mathrm{mL}$, chlorogenic acid $0.012 \mathrm{mg} / \mathrm{mL}$ 가 추출 되었고, $80^{\circ} \mathrm{C}$ 조건에서 caffeine $0.032 \mathrm{mg} / \mathrm{mL}$, chlorogenic acid $0.064 \mathrm{mg} / \mathrm{mL}$ 로 $80^{\circ} \mathrm{C}$ 조건에서 caffeine이 약 3 배 정도 의 추출 효율이, 약 5 배 정도의 chlorogenic acid 추출 효율 이 높은 것을 확인할 수 있었다.

본 연구에 이용한 모든 인체 유래 세포주의 배양은 Dulbecco's modified Eagle medium (DMEM) 배지에 10\% heat-inactivated fetal bovine serum (FBS)와 penicillin (100 U/ $\mathrm{mL}) /$ streptomycin $(100 \mu \mathrm{g} / \mathrm{mL})$ 을 첨가한 $\mathrm{DMEM}$ 배지를 사 용하였으며, $37^{\circ} \mathrm{C}, 5 \% \mathrm{CO}_{2}$ incubator에서 배양하였다. 시험 에 사용된 세포의 종류는 인체 유래 섬유아세포 $(\mathrm{CCD}$ 986sk)와 피부각질세포(HaCaT cell), 동물 유래 섬유아세 포(Vero cell)를 대상으로 배양하였다.

커피 원두 그린 추출물의 인체 유래 피부세포에 대한 독성을 확인하기 위해 MTT assay를 통해 세포 생존율 측 정을 Carmichael의 방법에 따라 측정하였고 실험에 사용 된 시료와 동량의 증류수를 첨가하여 대조군으로 사용하 였으며 추출물과 동일한 조건으로 배양하였다. 이에 $5 \mathrm{mg}$

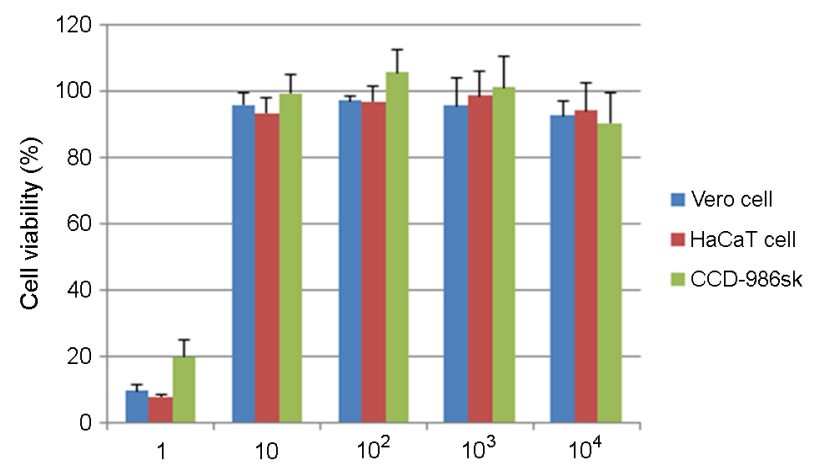

Fig. 3. Cell viability of coffee extracts on fibroblast (CCD-986sk, Vero Cell) and epithelial keratinocyte (HaCaT cell). The data were expressed as the mean \pm S.D. Results are representatives of more than three independent experiments.

$\mathrm{mL}$ 농도로 제조한 $\mathrm{MTT}$ 용액 $0.02 \mathrm{~mL}$ 을 첨가하여 4시간 배양한 후 배양액을 제거하고 각 well당 DMSO $0.2 \mathrm{~mL}$ 을 가해 실온에서 30 분 반응시킨 뒤 ELISA reader 기기를 사용하여 $595 \mathrm{~nm}$ 에서 흡광도를 측정하였고, 세포 독성 측 정은 시료용액의 첨가군과 무첨가군의 흡광도 감소율로 표시하였다.

커피 그린 추출물이 인체 유래 세포의 생존율에 미치는 영향을 확인하기 위하여 커피 추출물을 $1,10,10^{2}, 10^{3}, 10^{4}$ 의 농도로 희석 처리하여 인체 유래 세포와 함께 24시간 배양한 후에 MTT assay로 커피 그린 추출물의 세포에 관 한 독성 여부를 관찰하였다. 각 세포주에 대한 커피 추출 물의 세포 생존율을 측정한 결과, 추출물 원액에서 각각 $9.78 \%, 8.03 \%, 19.98 \%$ 의 세포 생존율을 나타내었고, 10 배 희석 농도 이하에서는 $90 \%$ 이상의 세포 생존율을 확인하 였다(Fig. 3).

$\mathrm{DPPH}$ (1, 1-diphenyl-2-picryl hydrazyl)는 화합물 내 질소 중심의 radical로 free radical의 안정화된 물질이기 때문에 반응 중 $\mathrm{DPPH}$ 의 감소는 free radical의 소거반응이 진행됨 을 알 수 있고 질소과산화의 초기반응의 억제 정도를 예 측할 수 있다. DPPH는 510 590 nm에서 최대 흡수를 나 타내며, 환원되면 흡수가 사라지기 때문에 $\mathrm{DPPH}$ 의 환원 정도는 환원제의 환원력에 따라 달라진다. 커피 그린 추 출물의 항산화 작용을 확인하기 위하여 $1,10,10^{2}, 10^{3}, 10^{4}$ 배로 희석된 커피 그린 추출물에 $\mathrm{DPPH}$ 를 이용 항산화 작 용을 측정하였다. 대조군으로 추출물 무첨가군을 대상으 로 비교한 결과 원액에서 가장 높은 $66 \%$ 의 저해활성이 나타났고 10 배 희석한 추출물에서는 $43.2 \%$, 그 이하로는 


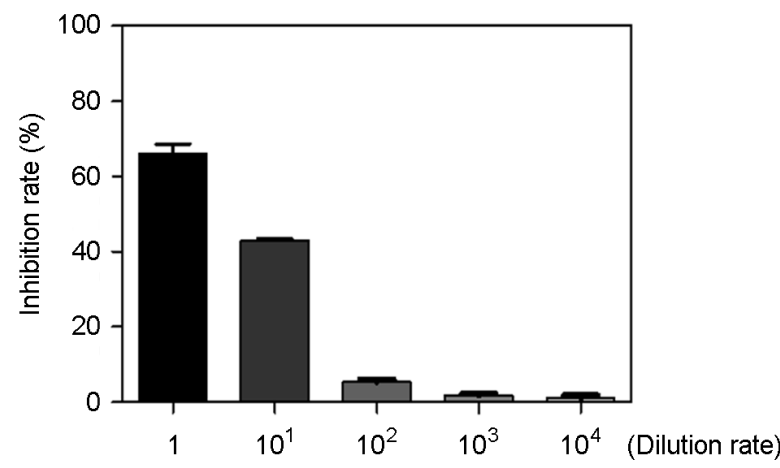

Fig. 4. Effect of coffee extracts on DPPH radical scavenging activities. The data were expressed as the mean \pm S.D. Results are representatives of more than three independent experiments.

$6 \%$ 미만의 낮은 저해활성을 확인할 수 있었다. 확인 결과 추출물의 농도 의존적으로 DPPH radical 소거작용을 나타 냄을 확인할 수 있었다(Fig. 4).

천연물질은 용매와 추출조건, 추출방법에 따라 추출되 는 성분들이 달라져 각각의 추출 효율에 있어서 차이가 나고 천연물질의 추출을 위해 초음파를 이용하였을 때 추 출수효율이 높게 나타난다는 연구 결과가 나오고 있다 (Jeon et al., 2015; Cho and Kim, 2016). 이번 연구에서 사용 한 원두 아라비카 종 이외에도 최근 다양한 종의 커피를 대상으로 연구가 진행되고 있고(Ayelign and Sabally, 2013; Jeszka-Skowron et al., 2016a) 커피를 음료로 사용하고 남은 부산물을 이용한 연구도 이뤄지고 있는 실정이다(Song et al., 2009; Lee and Park, 2015).

본 연구에서는 항산화 및 향균 효과가 있는 것으로 알 려진 원두커피에 대하여 추출방법을 초음파(증류수), 초 음파(식물성 에탄올), 초음파(에탄올) 추출법으로 각기 달 리하여 유효 성분을 추출한 후 각 추출물에서 caffeine과 chlorogenic acid의 함량을 분석함으로써 증류수로 추출했 을 때 각각 $127.62 \mathrm{mg} / \mathrm{mL}, 59.54 \mathrm{mg} / \mathrm{mL}$ 로 식물성 에탄올 과 합성 에탄올보다 더 높은 추출 효율을 가지는 것을 확 인하였다. 또한 커피의 추출이 $80 \sim 90^{\circ} \mathrm{C}$ 정도의 상온에서 효율이 높다는 연구 결과에(Salamanca et al., 2017) 따라 가 장 높은 추출 효율은 보인 증류수를 용매로 $50^{\circ} \mathrm{C}$ 와 $80^{\circ} \mathrm{C}$ 에서 측정한 결과 caffeine이 $0.032 \mathrm{mg} / \mathrm{mL}$, chlorogenic acid 가 $0.064 \mathrm{mg} / \mathrm{mL}$ 로 $80^{\circ} \mathrm{C}$ 의 상온에서 추출 효율이 높다는 것을 확인할 수 있었다. 커피 음료의 종류인 에스프레소 와 더치커피의 추출 시간이나 온도의 변화에 따라 추출 효율이나 항산화 효과의 변화를 보인다는 연구 결과가 보
고되어 커피추출물의 여러 가지 형태로의 이용가능성이 대두되고 있다(Hwang et al., 2013; Salamanca et al., 2017).

증류수를 용매로한 커피 추출물의 MTT assay와 DPPH 라디컬 소거능 활성 실험을 한 결과 3 종 모두에서 초음파 (증류수) 커피 추출물이 10 배의 희석 농도에서는 $90 \%$ 이 상의 생존률을 보여 세포 독성이 낮은 것을 확인하였고 $\mathrm{DPPH}$ 라디컬 소거능 효과는 원액에서 가장 높은 저해활 성이 나타났으며 농도 의존적으로 DPPH radical 소거작용 을 확인하였다. 이러한 결과로 미루어 볼 때 유기용매를 사용하지 않고 초음파(증류수) 추출법을 사용하여 상온에 서 추출하였을 때 가장 효율적인 것을 확인하였고, 이러한 커피 추출물이 세포 독성이 낮고 항산화 작용을 하기 때 문에 피부에서 흔히 발생하는 활성산소에 따른 노화를 방 지하는데 도움을 줄 수 있을 것이라고 기대하고, 추후 연 구에서는 커피 추출물을 이용한 화장품을 제작하여 사용 하였을 때 나타나는 피부의 변화를 관찰하여 피부의 노화 방지 효과를 확인할 예정이다.

\section{ACKNOWLEDGEMENTS}

본 연구는 중소기업청 2015년 산학연 협력 첫걸음 기 술개발사업의 지원으로 수행되었으며 이에 감사드립니다.

\section{CONFLICT OF INTEREST}

The authors have no conflicts of interest to disclose.

\section{REFERENCES}

Ayelign A, Sabally K. Determination of chlorogenic acids (CGA) in coffee beans using HPLC. American Journal of Research Communication. 2013. 1: 78-91.

Campos-Florián J, Bardales-Valdivia J, Caruajulca-Guevara L, Cueva-Llanos D. Anti-diabetic effect of coffea arabica, in alloxan-induced diabetic rats. Emirates Journal of Food and Agriculture. 2013. 25: 772-777.

Cho IH, Hong MS, Lee ES, Kim SJ, Lee YC, Kim SD, Jo HB, Kim JH, Jung K. Study of the characteristics of roasted coffee bean in Seoul. Journal of Food Hygiene and Safety. 2015. 30: 236 -241 .

Cho S, Kim $\mathrm{OH}$. Antioxidative activity and protein expression effects of the extracts from cinnamomum camphora on the hair-growth relevant factors. Asian Journal of Beauty Cosmetology. 2016. 14: 18-29.

Farah A, Monteiro M, Donangelo CM, Lafay S. Chlorogenic acids 
from green coffee extract are highly bioavailable in humans. The Journal of Nutrition. 2008. 138: 2309-2315.

Hur SS. Evaluation of Physiological Activities of cnidium officinale makino extracts with different solvents. Journal of Korean Oil Chemists' Society. 2015. 32: 170-179.

Hwang SH, Kim KS, Kang HJ, Kim MJ. Phenolic Compound contents and antioxidative effects on dutch coffee by extraction time. Korean Public Health Research. 2013. 39: 21-29.

Hwang HS, Park GD. A comparative study of anti-oxidant effect and cell proliferation effect based on extraction method of natural substances. Journal of Korean Beauty Society. 2015. 21: 729-736.

Jeon KM, Park KH, Pyo AJ. A research on cell proliferation effect and antioxidant activity of extracts based on different extraction methods of salvia miltiorrhiza bunge and scutellaria baicalensis. Korean Journal of Aesthetic Society. 2015. 13: 495-502.

Jeszka-Skowron M, Sentkowska A, Pyrzyn'ska K, De Peña MP. Chlorogenic acids, caffeine content and antioxidant properties of green coffee extracts: influence of green coffee bean preparation. European Food Research and Technology. 2016. 242: 1403-1409.

Kim W, Kim SY, Kim DO, Kim BY, Baik MY. Puffing, A novel coffee bean processing technique for the enhancement of extract yield and antioxidant capacity. Food chemistry. 2018. 240: 594-600.

Lee BE, Yang JC, Kim BA. A study of antioxidative and antimicrobial effects of coffee residue extracts. Journal of Korean Oil Chemists' Society. 2016. 33: 606-613.

Lee KS, Park KS. A study of effects of coffee waste extracts obtained from solvents. Korean Journal of Food and Nutrition. 2015. 28: 866-870.

Salamanca CA, Fiol N, Gonzalez C, Saez M, Villaescusa I. Extraction of espresso coffee by using gradient of temperature. effect on physicochemical and sensorial characteristics of espresso. Food chemistry. 2017. 214: 622-630.

Song EJ, Kim JY, Lee SY, Kim KBWR, Kim SJ, Yoon SY, Lee SJ, Lee CJ, Ahn DH. Effect of roasted ground coffee residue extract on shelf-life and quality of salted mackerel. Journal of Korean Society of Food Science and Nutrition. 2009. 38: 780 $-786$.

https://doi.org/10.15616/BSL.2017.23.4.388

Cite this article as: $\mathrm{H}$ Jin. Cell Proliferation and Antioxidative Effects of Ultrasonic Coffee Extracts. Biomedical Science Letters. 2017. 23: 388-394. 